Georgetown University Law Center

Scholarship @ GEORGETOWN LAW

2020

New Media, Free Expression, and the Offences Against the State Acts

Laura K. Donohue

Georgetown University Law Center, Ikdonohue@law.georgetown.edu

This paper can be downloaded free of charge from:

https://scholarship.law.georgetown.edu/facpub/2248

https://ssrn.com/abstract=3825722

Laura K. Donohue, New Media, Free Expression, and the Offences Against the State Acts, in The Offences Against the State Act 1939 at 80: A Model Counter-Terrorism Act? 163 (Mark Coen ed., Oxford: Hart Publishing 2021).

This open-access article is brought to you by the Georgetown Law Library. Posted with permission of the author. Follow this and additional works at: https://scholarship.law.georgetown.edu/facpub

Part of the Comparative and Foreign Law Commons, Constitutional Law Commons, European Law Commons, Human Rights Law Commons, International Law Commons, Internet Law Commons, Legislation Commons, and the National Security Law Commons 


\title{
New Media, Free Expression, and the Offences Against the State Acts
}

\author{
Laura K. Donohue ${ }^{1}$
}

\section{Introduction}

Social media has become an integral part of modern human interaction: as of October 2019, Facebook reported 2.414 billion active users worldwide. ${ }^{2}$ YouTube, WhatsApp, and Instagram were not far behind, with 2 billion, 1.6 billion, and 1 billion users respectively. ${ }^{3}$ In Ireland, 3.2 million people (66\% of the population) use social media for an average of nearly two hours per day. ${ }^{4}$ By 2022 , the number of domestic Facebook users is expected to reach 2.92 million. ${ }^{5}$ Forty-one percent of the population uses Instagram $(65 \%$ daily); $30 \%$ uses Twitter (40\% daily), and another $30 \%$ uses LinkedIn. ${ }^{6}$ With social media most prevalent amongst the younger generations, these numbers will only rise.

New media facilitates communication and creates a common, lived experience. It simultaneously carries the potential for great harm on an individual and societal scale. Scholars write about rising levels of depression and suicide that stem from online dependence and replacing analogical experience with digital interaction, as well as escalating levels of anxiety that find root in the validation expectation of the 'like'

\footnotetext{
${ }^{1}$ Many thanks to Dr. Mark Coen, Dr. Fergal Davis, and Sutherland School of Law for hosting the Offences Against the State Act Seminar in October 2019. I very much appreciated the participants' insights, as well as Dr. Coen's thoughtful suggestions on the manuscript. I am further indebted to Mr. Jeremy McCabe at the Georgetown Law library for his help in obtaining many of the materials used in writing this chapter.

${ }^{2}$ S Kemp, 'Digital 2019: Q4 Global Digital Statshot' (DataReportal, 23 October 2019) slide 24

https://datareportal.com/reports/digital-2019-q4-global-digital-statshot. See also 'Most Popular Social Networks Worldwide as of January 2020, Ranked by Number of Active Users' (Statista, 25 January 2020) www.statista.com/statistics/272014/global-socialnetworks-ranked-by-number-of-users/.

${ }^{3}$ ibid.

${ }^{4}$ S Kemp, 'Digital 2019: Ireland' (DataReportal, 31 January 2019) slides 19 and 31 https://datareportal.com/reports/digital-2019ireland.

${ }^{5}$ S O'Dea, 'Forecast of the Facebook User Penetration Rate in Ireland from 2015-2022' (Statista, July 2017), www.statista.com/statistics/566781/predicted-facebook-user-penetration-rate-ireland/. See also K Twomey, 'Social Media Stats Ireland 2019' (Communications Hub, 12 August 2019) http://communicationshub.ie/blog/2019/08/12/social-media-statisticsireland-2019/.

${ }^{6}$ ibid.
} 
function. ${ }^{7}$ Re-posting integrates emotion, with study after study finding that fear and anger transfer most readily online. ${ }^{8}$

Significant political risks also accompany this novel genre. Hostile actors can use social media platforms to deepen political schisms, to promote certain candidates, and, as demonstrated by the recent Cambridge Analytica debacle, to swing elections. ${ }^{9}$ Simultaneously, extremist groups and terrorist organisations can use online interactions to build sympathetic audiences and to recruit adherents. ${ }^{10}$

In Ireland, since 1939, the Offences Against the State Act (OAS) has served as the primary vehicle for confronting political violence and challenges to state authority. How effective is it in light of new media? The challenges are legion. Terrorist recruitment is just the tip of the iceberg. Social networking sites allow for targeted and global fundraising, international direction and control, anonymous power structures, and access to expertise. These platforms create spaces within which extreme ideologies can prosper, targeting individuals likely to be sympathetic to the cause, 24 hours a day, seven days a week, ad infinitum. They offer an alternative reality, subject to factual manipulation and direction - a problem exacerbated by the risk of so-called deep fakes: autonomously-generated content that makes it appear that people acted, or that certain circumstances occurred, which never did. ${ }^{11}$

In November 2019 the Irish Government adopted a new social media regulation. ${ }^{12}$ The measure targets political advertising and tries to ensure that voters have access to accurate information. ${ }^{13}$ It does not address the myriad further risks. This chapter, accordingly, focuses on ways in which the Offences Against the State Act (OAS) and related laws have historically treated free expression as a prelude to understanding how and whether the existing provisions are adequate for the types of challenges from new media.

\section{Origins}

\footnotetext{
${ }^{7}$ See, eg, C Newport, Digital Minimalism: Choosing a Focused Life in a Noisy World (New York, Portfolio/Penguin, 2019); JM Twenge et al, 'Increases in Depressive Symptoms, Suicide-Related Outcomes, and Suicide Rates Among U.S. Adolescents After 2010 and Links to Increased New Media Screen Time' (2018) 6 Clinical Psychological Science 3; H Clelland Woods and H Scott, '\#Sleepyteens: Social Media Use in Adolescence Is Associated with Poor Sleep Quality, Anxiety, Depression and Low Self-Esteem' (2016) 51 Journal of Adolescence 41; H Sampasa-Kanyinga and RF Lewis, 'Frequent Use of Social Networking Sites Is Associated with Poor Psychological Functioning among Children and Adolescents' (2015) 18 Cyberpsychology, Behavior, and Social Networking; J Fox and JJ Moreland, 'The Dark Side of Social Networking Sites: An Exploration of the Relational and Psychological Stressors Associated with Facebook Use and Affordances' (2015) 45 Computers in Human Behavior 168; JD Elhai et al, 'Fear of Missing Out, Need for Touch, Anxiety and Depression Are Related to Problematic Smartphone Use' (2016) 63 Computers in Human Behavior 509.

${ }^{8}$ PW Singer and ET Brooking, Like War: The Weaponization of Social Media (Boston, Houghton Mifflin Harcourt, 2018).

${ }^{9}$ C Cadwalladr, 'Fresh Cambridge Analytica Leak 'Shows Global Manipulation Is Out of Control'’ The Guardian (London, 4 January 2020) www.theguardian.com/uk-news/2020/jan/04/cambridge-analytica-data-leak-global-election-manipulation.

${ }^{10}$ Singer \& Brooking, Like War (2018) (n 8).

${ }^{11}$ B Chesney and D Keats Citron, 'Deep Fakes: A Looming Challenge for Privacy, Democracy, and National Security' (2019) 107 California Law Review 1753.

${ }^{12} \mathrm{H}$ McGee, 'New Legislation will Regulate Political Advertising on Social Media' Irish Times (Dublin, 5 November 2019). 13 ibid.
} 
Like the Irish Free State Constitution, the Treasonable Offences Act and the Public Safety Acts were forged in the fires of Irish Republicanism. Professor Thomas Mohr, in his chapter in this volume on precursors to the OAS, goes into detail on these acts and the conditions accompanying their introduction. This chapter focuses more narrowly on the provisions restricting free speech and association, arguing that the 1937 Constitution cemented many of these measures into the state structure. This, in turn, laid the groundwork for their further expansion in the 1939 Offences Against the State Act and its progeny.

\section{A. 1925 Treasonable Offences Act}

Outside of a narrow exception for public morality, the 1922 Free State Constitution protected free expression. ${ }^{14}$ But this guarantee proved unable to withstand the challenges posed by violent skirmishes, hunger strikes, and continued sympathy for anti-Treatyites. High unemployment and food shortages exacerbated civil, social, and political tension. Cuman na nGaedheal, which came into power in the August 1923 election, took steps to protect the fledgling state. Under the Treasonable Offences Act of 1925, it became an offence to conspire with or to incite others to attempt to overthrow the government of Saorstát Eireann. ${ }^{15}$ The statute forbade the administration or taking of any oath pledging to commit, promote, or conceal the commission of any crime. ${ }^{16}$ It also became illegal to refuse to speak when requested for information about any crime or breach of the peace. ${ }^{17}$

Although the government used the law to prosecute members of the Irish Republican Army (IRA), it proved problematic: during the 1916 Easter Rising, almost identical measures had been used by the British Crown. ${ }^{18}$ They had been designed to obtain a higher rate of conviction-not necessarily to ascertain guilt. The purpose behind making it easier to convict defendants stemmed from efforts to counter juror intimidation, but the result was a largely discredited statutory framework. The re-enactment of parts of the Treason Felony Act 1848 in the 1925 statute did little to demonstrate a break with the past. ${ }^{19}$ Ministers' consequent reluctance to use such provisions against their former comrades shifted the government's emphasis to the public safety acts and, thence, to the 1939 Offences Against the State Act.

\footnotetext{
${ }^{14}$ Constitution of the Irish Free State 1922, Art. 9. See also Censorship of Publications Act 1929, ss 6, 17 and 2; Censorship of Publications Act 1946; Censorship of Films Act 1923. For further discussion of censorship in Ireland for reasons of public morality see Kevin Rockett, Irish Film Censorship: A Cultural Journey from Silent Cinema to Internet Pornography (Dublin, Four Courts Press, 2004).

${ }^{15}$ Treasonable Offences Act 1925, s 1(c), (e).

16 ibid s $9(1)($ a).

17 ibid s $9(1)(\mathrm{c})-(\mathrm{d})$.

${ }^{18}$ M Head, Crimes against the State: from Treason to Terrorism (Farnham, Ashgate, 2011) 99; Treason Act 1795 (36 Geo 3 c 7 ) (Eng); Treason Act 1817 (57 Geo 3 c 6) (Eng); Treason Felony Act 1848 (11 \& 12 Vict c 12) (Eng).

${ }^{19}$ Compare Treasonable Offences Act 1925, s 3(1) and Treason Felony Act 1848 (11 \& 12 Vict. c 12) s 3 (Eng).
} 


\section{B. 1923-31 Public Safety Acts and Article 2A}

The 1923 Public Safety Act (PSA) was born of Civil War. It provided for broad powers of detention and internment. ${ }^{20}$ Punishments ranged from property seizure to flogging, imprisonment, and death. ${ }^{21}$ When the legislation expired, two provisions implicating speech took its place. But by far the most expansive public safety restrictions on free expression came in 1931 with the insertion of Article 2A into the constitution.

The PSA contained within its auspices powers of entry, search, seizure, and arrest for individuals suspected of incitement or encouraging officials to neglect their duties. ${ }^{22}$ In April 1924, a second Act made it illegal to induce a member of Saorstát Eireann to refuse their charge. ${ }^{23}$ Even encouraging individuals not to serve in government could result in imprisonment. In 1926, another Act made allowance for the proclamation of a public emergency during which the Executive Minister could assume extraordinary powers related to arrest and detention. ${ }^{24}$ These powers were premised in part on the foregoing crimes of incitement and inducement, as well as those detailed in the 1925 Treasonable Offences Act. ${ }^{25}$

The Civil War ended in 1923. Over the next decade, violence propagated by the IRA, Fianna Eireann, Cumann na mBan, Saor Eire, and the communist revolutionary groups proliferated. Cumann na nGaedheal, under W.T. Cosgrave's leadership, responded by ushering a new public safety statute through the Oireachtas, resulting in Article 2A's incorporation into the Irish Free State Constitution. ${ }^{26}$

In the Dáil, Cosgrave promoted suspending rights as a way to safeguard them. ${ }^{27}$ It was because of the protection of rights that violent agitation was unnecessary and, therefore, a legitimate target of new measures. ${ }^{28}$ The Minister for Defence, Desmond FitzGerald, took a more philosophical stance: 'Why have we a Constitution at all? Why have we a Government? Why have we a State?' ${ }^{29}$ To his mind, 'we have a

\footnotetext{
${ }^{20}$ Public Safety (Emergency Powers) Act 1923.

${ }^{21}$ ibid. See also Public Safety (Emergency Powers) (No 2) Act 1923; B Vaughan and S Kilcommins, Terrorism, Rights and the Rule of Law: Negotiating Justice in Ireland (Cullompton, Willan Publishing, 2008) 70.

${ }^{22}$ Public Safety (Powers of Arrest and Detention) Temporary Act of 1924, sch ss (1)-(2).

${ }^{23}$ Public Safety (Punishment of Offences) Temporary Act 1924.

${ }^{24}$ Public Safety (Emergency Powers) Act 1926, sch ss (1), (2), and (14). Legislation passed by the Parliament of Northern Ireland paralleled this statute. See Emergency Powers Act (NI) 1926 (16 \& 17 Geo 5 c 8) (empowering the Governor of Northern Ireland to declare a state of emergency).

${ }^{25}$ Public Safety (Emergency Powers) Act of 1926, schs ss (1), (2) and (14).

${ }^{26}$ Constitution (Amendment No 17) Act 1931. See also Ryan and Others (The State) $v$ Lennon and Others [1935] IR 170 (HC), 69 ILTR 125 (determining that the Oireachtas did not act ultra vires in passing the legislation). Cosgrave set two days in the Dáil and a day and a half in the Senead for the bill to go through all of its stages. William T. Cosgrave, Dáil Deb 14 October 1931, vol 40, col 29; Tomas O’Connell (Labour Party), Dáil Deb 14 October 1931, vol 40, col 61. Constitution of the Irish Free State 1922, Art. 50 provided and eight year grace period for the Oireachtas to amend the constitution without returning to the people for a referendum. The Oireachtas subsequently amended that article to extend the time period, with the result that from 1922 to 1937 , the constitution could be amended by statute, which it was, on 27 occasions. See G Hogan, The Origins of the Irish Constitution, 1928-1941 (Dublin, Royal Irish Academy, 2012) 4-8.

${ }^{27}$ William T. Cosgrave, Dáil Deb 14 October 1931, vol 40, col 31.

28 ibid.

${ }^{29}$ Desmond FitzGerald, Dáil Deb 14 October 1931, vol 40, col 69.
} 
Government and a State because we were made to live in society that man, being subject to the performance of evil, requires to be controlled by law. ${ }^{30}$ The fact that the measures were coercive did not make them any different from the Egg Grading Act or the Live Stock Bill. ${ }^{31}$ They were just directed at a serious threat. ${ }^{32}$ The failure to augment power would result in the dissolution of the state. ${ }^{33}$

Fianna Fáil and Labour objected to the measures' breadth and the speed with which they were being introduced. ${ }^{34}$ The statute's impact could hardly be ignored: 'The Constitution', Seán Lemass argued, 'may be the most glorious Constitution in the world, but it will be a dead letter before Friday evening if the Minister and his Party get their way'. ${ }^{35}$ The exceptions would abrogate constitutional rights. Lemass called out Cosgrave on the contradiction in stating that because rights were secure, they could be suspended to prevent violence, citing particular concern about the impact of the provisions on 'the right of free speech, the right of free assembly, [and] freedom of the Press. ${ }^{36}$

Article 2A did have a profound effect on constitutional rights. As Professor Mohr notes in his chapter, its primary purpose was to establish an emergency court with extraordinary powers. ${ }^{37}$ Most pertinent for this chapter, freedom of expression did not escape the net. The statute made it illegal to possess any treasonable or seditious documents, defined in terms of unlawful associations: i.e., a document related to any group that promoted, encouraged, or advocated (a) any act of a treasonable or seditious character, (b) the commission of any offence, (c) the obstruction of justice; or (d) non-payment of taxes. ${ }^{38}$ The burden was on the person on whose property or person such documents were found to demonstrate to the satisfaction of the Court (or the Special Tribunal) either that he did not know that the material was in his possession, or was unaware of the contents. ${ }^{39}$ Otherwise, possession demonstrated membership. ${ }^{40}$

The statute made further inroads into free expression. It prohibited printing, publishing, selling, or distributing 'any book, newspaper, magazine, periodical, pamphlet, leaflet, circular, or other document' on behalf of unlawful associations, regardless of their content. ${ }^{41}$ 'Print' was construed broadly to mean any

\footnotetext{
30 ibid.

31 ibid col 70. See eg Agricultural Produce (Eggs) Act, 1924, No. 35, s 14; Agricultural Produce (Eggs) Act, 1930 , No. 36 , s 11.

32 ibid.

33 ibid col 78 .

${ }^{34}$ See, eg, Eamon de Valera, Dáil Deb 14 October 1931, vol 40, cols 58, 61; Tomas O’Connell (Labour Party), Dáil Deb 14 October 1931, vol 40, col 62.

${ }^{35}$ Seán Lemass, Dáil Deb 14 October 1931. vol 40, col 81.

36 ibid cols 85-86. For a direct response to Lemass, see Minister for Justice, James Fitzzgerald-Kenney, Dáil Deb 14 October 1931, vol 40, col 110 .

${ }^{37}$ Accordingly, it empowered the Executive Council to declare a state of emergency suspending certain constitutional clauses; created a Special Powers Tribunal for political crimes; introduced new arrest powers; and provided for proscription. See Constitution (Amendment No 17) Act 1931. See also Constitution (Operation of Article 2A) Order 1931, SR\&O 1931/72 (bringing in the provision).

${ }^{38}$ Constitution (Amendment No 17) Act 1931, sch (3)(1); Constitution of the Irish Free State Art. 2A(3)(1), (19)(1)(a)-(f); ibid Art 2A(21).

39 ibid.

40 ibid Art 2A(22)(1).

${ }^{41}$ See ibid Art 2A(23)(1)-(2).
} 
mode of representing or reproducing words in visible form. ${ }^{42}$ It captured any notes made at a meeting; letters or invitations sent by members of the group; or announcements of planned events. The Special Tribunal could declare any periodical seditious and order the Garda Síochána to search for and seize it. ${ }^{43}$

Treasonable documents also became a trigger for extraordinary stop, search, and arrest powers. ${ }^{44}$ The statement by any member of the Gardaí that he suspected an individual to be carrying seditious material was treated as 'conclusive and final evidence, incapable of being rebutted or questioned by crossexamination' as a rationale for arrest. ${ }^{45}$ For home searches, the presence of treasonous documents became sufficient for the reasonableness determination. ${ }^{46}$ Any documents seized could be destroyed. ${ }^{47}$

Fianna Fáil, which had bitterly opposed the statute, ended the emergency when it came to power in 1932 leaving the Gardaí with ordinary criminal law to counter the IRA. ${ }^{48}$ The suspension of parts II to V of Article 2A, however, did not revoke the Constitution (Amendment No 17) Act of 1931, leaving the underlying powers in place. Following almost nightly confrontations between the Blueshirts and the IRA, in 1933 Éamon de Valera re-activated Article 2A and banned the Blueshirts. ${ }^{49}$ Three years later, he extended it to the IRA. ${ }^{50}$

\section{The 1937 Irish Constitution}

In 1934, Fianna Fáil began to prepare a new constitution. Foremost in the Committee's mind was the concentration of power in Article 2A. ${ }^{51}$ Following intense debate and multiple amendments, the new constitution passed by national plebiscite, coming into force in December 1937. Bunreacht na hÉireann repealed section $2 \mathrm{~A}$, placing more restrictions on the use of emergency powers, even as it conditioned the right of free expression. ${ }^{52}$ It borrowed the speech clause from the earlier constitution and divided it into three sections. The document augmented concerns about public morality with the assurance that freedoms

\footnotetext{
${ }^{42}$ See ibid Art 2A(23)(3).

43 ibid Art 2A(26).

44 ibid Art 2A(29)(1).

45 ibid Art 2A(29)(2).

46 ibid Art $2 \mathrm{~A}(30)(1)$.

47 ibid Art 2A(32).

${ }^{48}$ Constitution (Suspension of Article 2A) Order 1932, SR\&O 1932/11 (suspending Parts II-V of Article 2A as authorised under Article 2A(1)(3)).

${ }^{49}$ Constitution (Operation of Article 2A) Order 1933, SR\&O 1933/91; Constitution (Declaration of Unlawful Association) Order 1933, SR\&O 1933/95; Constitution (Declaration of Unlawful Association) (No 2) Order 1933, SR\&O 1933/189.

${ }^{50}$ Constitution (Declaration of Unlawful Association) Order 1936, SR\&O 1936/172 (banning the Irish Republican Army / IRA / Oglaigh na hEireann under Article 2A(19)(2)).

${ }^{51}$ DK Coffey, Drafting the Irish Constitution 1935-1937: Transnational Influences in Interwar Europe (Cham, Palgrave Macmillan, 2018) 188, 193. See also G Hogan, 'The Constitution Review Committee of 1934' in FÓ Muircheartaigh (ed), Ireland in the Coming Times: Essays to Celebrate T.K. Whitaker's 80 Years (Dublin, Institute of Public Administration, 1997).

${ }^{52}$ Constitution of Ireland (Bunreacht na hÉireann) 1937.
} 
would not be used to undermine the state - in essence, constitutionalising the exceptions in the public safety acts. $^{53}$

The new speech clause established '[t]he right of the citizens to express freely their convictions and opinions', while placing controls on the radio, press, and film industry to ensure that communication not be used to undermine public order or morality, or the authority of the state. ${ }^{54}$ The document incorporated the 1925 Treasonable Offences Act, prohibiting '[t]he publication or utterance of seditious' (as well as indecent) matter. ${ }^{55}$

The 1937 Constitution separated out the right of assembly, allowing for peaceable congregation (absent munitions), even as it empowered the Government to prevent or control meetings 'calculated to cause a breach of the peace or to be a danger or nuisance to the general public. ${ }^{56}$ Like the speech provisions, the change reflected the Article 2A approach, with unlawful associations premised on the marshalling of force against the government. ${ }^{57}$ It weighed the exception to the right against the communal interest in protecting the state. The Constitution forbade laws regulating associations from discriminating based on political, religious, or class distinctions. ${ }^{58}$ Nevertheless, treasonous, anti-constitutional associations could not rely on Article 40 for protection.

Since Article 2A of the prior constitution had not been continued, the new document superseded the earlier provisions. Article 40 thus functioned to fold in press and publication elements as a basis for considerations related to speech and the associative rights. Despite the incorporation of elements of the Treasonable Offences Act into the new Constitution, the 1925 statute, as well as the 1926 Public Safety (Emergency Powers) Act remained in place.

\section{The Offences Against the State Act}

The 1939 OAS passed amidst heightened global political tension, as, from east to west, democracies were being threatened. ${ }^{59}$ In 1932, following the assassination of Prime Minister Inukai Tsuyoshi, the Japanese military assumed control of the state. In Spain, a coup by right-wing military leaders in 1936 led to Civil War. In Germany, Adolf Hitler and the Third Reich abolished the presidency and introduced extraordinary powers. ${ }^{60}$ In 1938 , the country annexed Austria and, the following year, laid claim to parts of

\footnotetext{
${ }^{53}$ Compare above n 14 and Constitution of Ireland 1937, Art 40.6.1 ${ }^{\circ}$.i-iii.

${ }^{54}$ Constitution of Ireland 1937, Art 40.6.1 $1^{\circ}$.i.

55 ibid.

56 ibid Art 40.6. $1^{\circ}$.ii.

${ }^{57}$ See ibid Art 40.6.1 $1^{\circ}$.iii.

58 ibid Art 40.6.2 ${ }^{\circ}$.

${ }^{59}$ Offences Against the State Act 1939 (OAS 1939).

${ }^{60} \mathrm{See}$, eg, Law for the Prevention of Offspring with Hereditary Diseases (Gesetz zur Verhütung erbkranken Nachwuchses) s 1 ,

1933 RGB1 I, 529 (creating a Genetic Health Court (Erbgesundheitsgericht) and mandating forced sterilisation for persons with
} 
Czechoslovakia. Benito Mussolini, having established an authoritarian regime in Italy, invaded Albania. Concern about the international backdrop wove its way into OAS debates. ${ }^{61}$ In some ways, it made restrictions more palatable, as the issue was how to protect democracy—not, more narrowly, whether to incorporate the six counties or respond to those willing to use violence to do so. Nevertheless, the immediate rationale offered by the Government followed the familiar line, justifying new restrictions on speech, publication, and association by reference to Republican dissidents.

\section{Broader Context and Supporting Arguments}

In 1939, the spectre of WWII hung over debates in the Oireachtas. In the Seanad Professor Helena Concannon explained, 'It is because ours is a democratic State - and most of us wish it to remain suchthat the Government we have chosen for ourselves must be provided by us with the powers necessary to protect the State. ${ }^{62}$ Looming large were the "many examples in recent years of the dangers to democratic governments if they are left defenceless and if they have not those necessary powers. ${ }^{93}$ The Fianna Fáil leader (and a senior member of the IRA in County Tipperary during the War of Independence), William Quirke, underscored the importance of restricting freedom to protect democracy in light of the changed circumstances. ${ }^{64}$

Members of Dáil Éireann similarly recognised the new kind of threat. James Matthew Dillon argued that 'in recent years, the technique of potential tyranny has completely changed. ${ }^{\prime 65}$ Rights made democratic states vulnerable, as those seeking 'to destroy democratic government' could 'use the very privileges conferred by the Constitution for the purpose of destroying the Constitution itself. ${ }^{96} \mathrm{He}$ warned that "while democracy is shivering on the brink' authoritarian adherents could 'give democracy the felon's blow, destroy it and grab power and after they have grabbed power then proceed to subjugate the people. ${ }^{67}$

While some members of the Oireachtas argued that the threat facing democracy required extraordinary measures, the government cited the IRA's resumption of its violent campaign in Britain and the continued

\footnotetext{
certain physical and mental disabilities or chronic alcoholism); Law against Dangerous Habitual Criminals and on Measures for Security and Improvement (Gesetz über die gefährliche Gewohnheitsverbrecher und über Massregeln zur Sicherung und Besserung), 1933 RGB1 I, 995 (providing for indefinite detention, inter alia); Law on Treason, 1934 RGB1 I, 341 (Ger) (making most activities of opposition groups punishable by death).

61 The situation on the continent also played a role in the adoption of the First Amendment of the Constitution Act 1939, which amended the definition of 'time of war' in Article $28.3 .3^{\circ}$ to include a situation in which Europe was at war, while Ireland was technically at peace. See Hogan, Origins (n 30) ch 13.

62 Professor Helena Concannon, Seanad Deb 3 May 1939, vol 22, col 1540. See also ibid col 1539-40.

63 ibid.

${ }^{64}$ See, eg, William Quirke, Seanad Deb 4 May 1939, vol 22, col 1557.

65 James Matthew Dillon, Dáil Deb 3 March 1939, vol 74, col 1440.

66 ibid.

67 ibid.
} 
challenge of Republicanism in justification. ${ }^{68}$ Numerous members oppugned this rationale, citing the absence of evidence that such a campaign was underway. ${ }^{69}$ They expressed alarm about normalising extraordinary powers at a time of relative peace. ${ }^{70}$ Without evidence, it was hard to justify the restrictions on freedom of expression and of the press. ${ }^{71}$ General Seán MacEoin doubted that a sub-constitutional instrument could deprive citizens of their fundamental rights. ${ }^{72}$ Fine Gael politician and future Attorney General Patrick McGilligan noted: 'We have a series of Articles in our Constitution which state fundamental principles and rights. It has stated them with so many reservations that the rights and liberties have almost disappeared. The law may change, and if it does change the fundamental rights under the Constitution are gone. ${ }^{73} \mathrm{He}$ despaired of the impact of the OAS on '[m]atters affecting conscience', 'freedom of the Press, and freedom to speak one's thoughts. ${ }^{74}$

Foremost in the Opposition's mind was the potential for abuse. ${ }^{75}$ The same objections had been brought forward during the passage of the notorious 1931 Public Safety Act, eliciting guarantees that the powers would be used appropriately. Nevertheless, they had been misapplied. ${ }^{76}$ Backbenchers observed that while Fianna Fáil might be in power now, in the future, they too could become subject to a different government wielding the measures against them. In the Seanad, Cumann na nGaedheal politician John McLoughlin made dire predictions, quoting Shelley: 'I met Murder on the way,/He wore the mask of Castlereagh,/ Very smooth he looked, yet grim,/ Seven bloodhounds followed him. ${ }^{77}$

Despite such misgivings, the OAS passed the Dáil 53 to 8 and the Seanad 28 to $9 .{ }^{78}$ It might have been that international concerns loomed large; but the language continued to be redolent of anti-Treaty challenges to the state. The restrictions on freedom of expression, in particular, targeted Republican activities.

\section{Impact of the 1939 OAS on Speech, Expression, and the Associative Rights}

\footnotetext{
${ }^{68}$ See Seán Goulding, Seanad Deb 4 May 1939, vol 22, col 1551; William Davin, Dáil Deb 7 March 1939, vol 74, col 1565; Patrick Joseph Ruttledge, Dáil Deb 8 Feb 1939, vol 74, col 90. See also William Quirke, Seanad Deb 4 May 1939, vol 22, col 1554-55.

${ }^{69}$ See, eg, John McLoughlin, Seanad Deb 3 May 1939, vol 22, col 1526; Patrick Hogan, Seanad Deb 3 May 1939, vol 22, col 1534; William Davin, Dáil Deb 7 March 1939, vol 74, col 1564; William Davin, Dáil Deb 3 March 1939, vol 74, col 1476; General Seán MacEoin, Dáil Deb 7 March 1939, vol 74, cols 1565-66; Patrick Belton, Dáil Deb 3 March 1939, vol 74, col 1459; Captain Patrick Giles, Dáil Deb 2 March 1939, vol 74, col 1356-57; ibid col 1358.

${ }^{70}$ See, eg, Seán Brodrick, Dáil Deb 2 March 1939, vol 74, col 1375.

${ }^{71}$ See, eg, Patrick Hogan, Seanad Deb 3 May 1939, vol 22, cols 1536-37.

72 General Seán MacEoin, Dáil Deb 7 March 1939, vol 74, col 1566.

${ }^{73}$ Patrick McGilligan, Dáil Deb 2 March 1939, vol 74, cols 1399-1400.

74 ibid col 1400 .

${ }^{75}$ See, eg, Patrick Cogan, Dáil Deb 2 March 1939, vol 74, col, 1300.

76 ibid ('[T]he people who introduced that measure and sponsored it and succeeded in getting it passed were the very people who were penalised afterwards by the Act.').

77 John McLoughlin, Seanad Deb 3 May 1939, vol 22, col 1531.

${ }^{78}$ Dáil Deb 27 April 1939, vol 74, col 1274; Seanad Deb 31 May 1929, vol 22, col 1634.
} 
The 1939 OAS had immediate implications for freedom of expression. The statute made it illegal to advocate the usurpation or unlawful exercise of government functions (s 6); to obstruct legislative, executive, or judicial functions (s 7); or to incite or encourage any government employee to refuse, neglect or omit to perform their duties (s 9). It also created new strictures to deal with printed matter.

The statute prohibited printing, publishing, selling, or distributing incriminating material (books, newspapers, magazines, publications, pamphlets, circulars, or advertisements) ${ }^{79}$ Like section $2 \mathrm{~A}$, content did not matter. Instead, it defined such material as anything issued by or "emanating from an unlawful organisation' or 'appearing to aid or abet any such' entity. ${ }^{80}$ The statute forbade treasonable, as well as seditious documents, the latter being understood in particularly broad terms - ie,

(a) a document consisting of or containing matter calculated or tending to undermine the public order or the authority of the State, and

(b) a document which alleges, implies, or suggests or is calculated to suggest that the government functioning under the Constitution is not the lawful government of the State or that there is in existence in the State any body or organisation not functioning under the Constitution which is entitled to be recognised as being the government of the country, and

(c) a document which alleges, implies, or suggests or is calculated to suggest that the military forces maintained under the Constitution are not the lawful military forces of the State, or that there is in existence in the State a body or organisation not established and maintained by virtue of the Constitution which is entitled to be recognised as a military force, and

(d) a document in which words, abbreviations, or symbols referable to a military body are used in referring to an unlawful organisation. ${ }^{81}$

It thus outlawed any effort to undermine the legitimacy of the Irish government as a political entity. It did not draw attention to what form that government ought to take (eg, an autocracy, oligarchy, democracy, or republic) - a consideration already addressed in Article 5 of the Constitution. It similarly forbade documents related to paramilitary organisations as an alternative to the existing military-again reflecting the Republican challenge. The statute made it illegal to send or to publish any incriminating, treasonous, or seditious document, with penalties ranging from a fine and imprisonment to forfeiture. ${ }^{82}$ Parliamentarians

\footnotetext{
${ }^{79}$ Offences Against the State Act 1939 (OAS 1939), s 2.

${ }^{80}$ ibid.

81 ibid.

82 ibid s 10(2)-(3).
} 
expressed alarm at the potential use of the measure to stifle political dissent ${ }^{83}$ Even if the 'truth' could be published, political critique might not escape. The government swept aside these objections.

With the international arena in mind, some politicians raised concern about the threat of foreign control or manipulation of Ireland. ${ }^{84}$ The Government responded that the penetration of Ireland by foreign publications was already covered by the provisions. ${ }^{85}$ This explanation did not satisfy the Irish press, which was alarmed by the potential for unfair competition. ${ }^{86}$ The Seanad, accordingly, brought in an additional measure targeting foreign newspapers. ${ }^{87}$ It provided for the Minister of Justice to prevent foreign papers from entering the country and to seize them within domestic bounds. ${ }^{8}$ Introducing the measure in Dáil Éirean, the Minister for Justice, Patrick Joseph Ruttledge, further raised the importance of not putting distributors in the position of censor. ${ }^{89}$

The 1939 OAS also outlawed possession of incriminating, treasonable, or seditious documents. ${ }^{90}$ Like section 2A, the burden was on the defendant to demonstrate that he did not know that he had the document, or that he did not know the nature of its contents. ${ }^{91}$ Where publishers found themselves in possession of such material and the Gárda Síochána requested it, they had the option of either turning it over to the police or destroying the document. ${ }^{92}$ This clause had been put forward at the request of Dublin newspapers to ensure the continued protection of their sources. ${ }^{93}$ During the Committee stage, the government added a provision to require printers to retain copies of the documents, as well as particulars of the person for whom the work was done, for six months following publication, to be turned over to the Gárda Síochána upon request. ${ }^{94}$ Publishers also became required to put their name and address on every document. ${ }^{95}$

The Government quickly used its new power. On June 23, 1939, it issued an order, citing to sections 18 and 19 of the OAS, and stating that 'the Government are of opinion that the organisation styling itself the Irish Republican Army (also the I.R.A. and Oglaigh nah Eireann) is an unlawful organization. ${ }^{96}$ Depending upon the level of Republican agitation, the Government exercised its authority under the order. In 1955, for instance, the Taoiseach, John Costello, met with the editors of the Irish newspapers to remind

\footnotetext{
${ }^{83}$ See, eg, William Davin and Richard Corish, Dáil Deb 7 March 1939, vol 74, cols 1562-63.

${ }^{84}$ See, eg, Frank Aiken, Minister for Defence, Dáil Deb 3 March 1939, vol 74, cols 1436-37.

${ }^{85}$ See, eg, Desmond Fitzgerald, Seanad Deb 31 May 1939, vol 22, col 1624.

${ }^{86}$ William Quirke, Seanad Deb 17 May 1939, vol 22, col 1594.

${ }^{87}$ The measure was adopted as Amendment 2 in the Seanad. See OAS 1939, s 11.

${ }^{88}$ ibid s 11(1).

${ }^{89}$ Patrick Joseph Ruttledge, Dáil Deb 6 June 1939, vol 76, col 581.

${ }^{90}$ OAS 1939, s 12(1).

91 ibid s 12(3).

92 ibid s 12(5).

${ }^{93}$ Patrick Joseph Ruttledge, Dáil Deb 6 June 1939, vol 76, cols 581-82 (Amendment 3 in the Seanad).

${ }^{94}$ OAS 1939, s 13(1)(b). See also Patrick Joseph Ruttledge, Seanad Deb 31 May 1939, vol 22, col 1624-25 (inserting s 13(1)(a)(c)).

95 OAS 1939, s 14(1).

${ }^{96}$ Unlawful Organisations (Suppression) Order 1939, 23 June 1939. See also 'Suppression Order Still In Force' (Irish Times, 3 December 1955) 1,8 .
} 
them that the IRA was an unlawful organisation in respect to which an OAS Suppression Order had been issued. The government warned that the order would be enforced.$^{97}$ It went on to make use of the provision during the IRA's Border Campaign 1956-1962. In 1957, ten men were sent to prison for, alternately, failing to give an account of their movements and actions over a specified period, being a member of a proscribed organizations, and being in possession of incriminating documents. ${ }^{98}$ That same year, charges were brought against two men in Cork for membership of an illegal organisation, possession of incriminating documents, and failing to answer questions in connection with the commission of an offence by others. The documents related to the purchase of sleeping bags, ground sheets, haversacks, uniforms and spirit lamps, and the payment of money. One of the documents contained the heading, 'Irish Resistance to British Aggression. ${ }^{99}$ During the trial the public galleries were filled. Some 300 people gathered in the streets outside on the final day, alternately cheering and booing the authorities for use of the power. ${ }^{100}$

\section{Evolution of OAS}

The OAS underwent four amendments, three of which implicated free speech and expression. ${ }^{101}$ Like the initial provisions, the new clauses reflected the Republican challenge.

The first change, the 1940 Offences Against the State (Amendment) Act, expanded the government's authority to determine what statements undermined public order. ${ }^{102}$ Section 4(1) empowered a Minister of State to order the arrest and detention of anyone 'engaged in activities which, in his opinion, are prejudicial to the preservation of public peace and order or the security of the State' ${ }^{103}$ Reminiscent of the 1922 Civil Authorities (Special Powers) Act provision granting the Northern Ireland Prime Minister the power 'to take all such steps and issue all such orders as may be necessary for preserving the peace and maintaining order', designation in the Republic could be based entirely on speech, expression, or associations considered by the Minister to be a threat. ${ }^{104}$

History has not treated section 4(1) kindly. In 1999, the Government established the Committee to Review the Offences Against the State Acts 1939 to 1998 under the chairmanship of Justice Anthony J. Hederman. In its final report, the committee wrote: ' $[\mathrm{O}]$ ne must ... regard the [provision] as constituting a

\footnotetext{
97 'Suppression Order Still In Force' (Irish Times, 3 December 1955) 1, 8.

98 'Charges Under Offences Against State Act: Ten Men Sent to Prison' (Irish Times, 26 January 1957) 9.

99 'Crowd Boohs After Cork Court Case' (Irish Times, 28 January 1957) 3.

100 ibid.

${ }^{101}$ Offences Against the State (Amendment) Act 1940 (OASA 1940), Offences Against the State (Amendment) Act 1972 (OASA

1972), [Offences Against the State (Amendment) Act 1985 (nothing on speech/press/publication; focused on banks)], and

Offences Against the State (Amendment) Act 1998 (OASA 1998).

102 See OASA 1940.

103 ibid s 4.

${ }^{104}$ Civil Authorities (Special Powers) Act (Northern Ireland) 1922, s 1(1).
} 
draconian interference with fundamental rights to liberty, due process, freedom of expression and freedom of association. ... [T] he powers in question are inconsistent with the basic tenets of democracy and the rule of law, and it is inappropriate that a liberal democracy should retain them on its statute book in the twentyfirst century.' 105

In 1972, the Oireachtas again amended the OAS, adding a clause that allowed for membership in an unlawful organisation to be predicated upon any oral or written statement. ${ }^{106}$ The statute outlawed any statement or meeting that interfered with the 'course of justice'-ie, anything intended, or likely (directly or indirectly) 'to influence any court, person or authority' concerned in criminal proceedings-including as a party or witness - the conduct or outcome of such proceedings. ${ }^{107}$ The statute amended the definition of 'document' to incorporate any map, plan, graph, or drawing; photograph; digital media; and film, microfilm, or tape. ${ }^{108}$

During the mid-1970s, political leaders, citing to the OAS, again reminded journalists that the law prohibited them from publishing statements by proscribed organisations. ${ }^{109}$ The government went on to make direct use of the power. In 1973, for instance, printers from Drogheda were charged under the OAS for printing the book Freedom Struggle. ${ }^{110}$ The cover of the publication featured a person dressed in military-type uniform with a sub-machine gun. The Gardaí seized the printed books, the plates, and other information related to publication. ${ }^{111}$ The following year the editor of An Phoblacht, Eamonn MacThomais, was sentenced to 15 months' imprisonment under the OAS for IRA membership and possession of an incriminating document. ${ }^{12}$ The 1972 amendment generated significant concern among journalists, spurring the National Union of Journalists (NUJ) to make numerous representations to the Government. ${ }^{113}$

Following a series of high-level IRA operations, in 1976 the Fine Gael-Labour coalition introduced an Emergency Powers Act that increased detention from 48 hours to seven days. ${ }^{114}$ In concert with the measure, a new Criminal Law Bill sought to strengthen section 10 of the 1939 OAS. ${ }^{115}$ The new offence of incitement was initially drafted broadly enough to encompass the print media-essentially creating a section 31 corollary. Conor Cruise O’Brien, Labour Minister for Posts and Telegraphs, explained that the

\footnotetext{
${ }^{105}$ Committee to Review the Offences against the State Acts 1939 to 1998, Report of the Committee to Review the Offences Against the State Acts, 1939 - 1998 and Related Matters (Dublin, Stationary Office, 2002) para 5.67.

106 OASA 1972, s 3(1)(a). Professor Liz Heffernan's chapter in this collection focuses on belief evidence in the context of membership in proscribed organizations.

107 ibid s 4(1).

108 ibid s 5(a)-(d).

109 'Kelly Critical of Journalists' (Irish Times, 14 November 1975) 13

110 'Company and Two Employees Are Charged with Printing Seditious Document Booklet by the Provisional I.R.A.' (Irish

Times, 6 November 1973) 13.

111 ibid.

112 'Journalists Concerned at Jailing of Editor' (Irish Times, October 10, 1974) 1.

${ }^{113}$ See Dick Walsh, Journalists Concerned at Jailing of Editor, Irish Times, 10 October 1974, p. 1; Kelly Critical of Journalists, Irish Times, 14 November 1975, p. 13.

${ }^{114}$ Emergency Powers Act, 1976, No. 33, section 2(3).

${ }^{115}$ Criminal Law Act, 1976, No. 32, section 3.
} 
provision would be used to prosecute editors of newspapers who published readers' letters to which the government objected. ${ }^{116}$ The Attorney General confirmed the government's intent to a reporter from the Irish Press. ${ }^{117}$ A bitter fight ensued, in the course of which the bill was amended to exclude the media provisions.

Following the Omagh bombing, the Oireachtas further curtailed the right to silence for individuals accused of membership of a proscribed entity, allowing for an inference of guilt. ${ }^{118}$ It allowed for the failure to provide a full account of one's 'movements, actions, activities, or associations during any specified period' to be treated as corroborating evidence. ${ }^{119}$ The law further amended the prior definition of conduct to include failure to deny published reports of membership. ${ }^{120}$ And it made it unlawful to collect, record or possess information that would be useful for unlawful organisations to engage in a serious offence. ${ }^{121}$ The burden lay on the defendant to demonstrate that they were not collecting the information for such purpose. ${ }^{122}$

Constitutional challenges to the OAS provisions governing speech have been relatively few and far between. None have succeeded. In People (DPP) v. O'Leary, for instance, a poster depicting a man in paramilitary gear and the slogan 'IRA calls the shots,' constituted incriminating material within the meaning of section 10 of the OAS. ${ }^{123}$

\section{E. Emergency Powers Act}

On 2 September 1939 the Irish government declared a state of emergency in response to the outbreak of the war. The following day, the Oireachtas introduced the Emergency Powers Act, giving the government the power to make by order, 'such provisions as are, in the opinion of the Government, necessary or expedient for securing the public safety or the preservation of the State, or for the maintenance of public order, or for the provision and control of supplies and services essential to the life of the community'. ${ }^{124}$

Like the OAS, the law targeted speech to head off violent political opposition. The Act empowered the Minister to 'authorise and provide for the censorship, restriction, control, or partial or complete suspension of communication by means of all or one or more of the services maintained or controlled by the Minister

\footnotetext{
${ }^{116}$ M O'Brien, The Fourth Estate: Journalism in Twentieth-Century Ireland (Manchester, Manchester University Press, 2017), p. 145. 
for Posts and Telegraphs or by any other means'. ${ }^{125}$ Such orders could contain 'all such incidental or ancillary provisions as shall appear to the Government to be necessary or expedient' ${ }^{126}$

In April 1946, the Minister for Finance, Frank Aiken, informed the Dáil that the Government had made 7,846 Emergency Powers Orders (and amendments thereto), of which 522 had been primary orders. ${ }^{127}$ The censorship provisions in particular were used extensively to protect Irish neutrality. ${ }^{128}$ In September 1946, the statute formally lapsed. ${ }^{129}$

\section{Broadcast and Film Restrictions}

While there is significant coverage in the secondary literature of ways in which the right to silence has been impacted by the OAS, there is less discussion of how OAS provisions targeting expression and association have affected individual rights. ${ }^{130}$ One reason may be because there is an alternative, more visible, framework: statutes directly regulating broadcast, film, and publication. ${ }^{131}$ From the founding of the Irish Free State until the end of the 20th century, the government made use of these provisions to respond to political violence and challenges to state legitimacy. The most salient are the statutes related to broadcasting, although some of the film restrictions also played a role. The censorship of publications, in contrast, largely centered on preventing indecent or obscene material, or matters related to abortion, from entering the public domain.

\section{A. Broadcast Bans}

Various laws regulate broadcasting in Ireland, with the structure itself providing a way to control speech. ${ }^{132}$ While civil servants are expected to be apolitical, where they fail to walk the government line, they can be-and are-fired, particularly when it comes to efforts to control messaging related to

\footnotetext{
125 ibid s 2(2)(h).

126 ibid s 2(4).

${ }^{127}$ Frank Aiken, Dáil Deb 11 April 1946, vol 100, col 1766.

${ }^{128}$ See generally T Gray, The Lost Years: The Emergency in Ireland 1939-45 (London, Little, Brown, 1997).

${ }^{129}$ Emergency Powers (Continuance and Amendment) Act 1945.

${ }^{130}$ See, eg, L Heffernan, 'Evidence and National Security: Belief Evidence in the Irish Special Criminal Court' (2009) 15 European Pubic Law 65; YM Daly, 'Is Silence Golden? The Legislative and Judicial Treatment of Pre-Trial Silence in Ireland' (2009) 31 Dublin University Law Journal 35 (2009); L Campbell, 'Reconfiguring the Pre-Trial and Trial Processes in Ireland in the Fight against Organised Crime' (2008) 12 International Journal of Evidence \& Proof 208; C Harte, 'The Offence of Membership of an Unlawful Organisation and the Evidential Provisions Relating to It, under the Offences Against the State Acts, 1939-1998' (2010) 17 Irish Student Law Review 51; SC Friends, 'An Effective Way to Deal with Terrorism? Britain and Ireland Restrict the Right to Silence' (1999) 23 Suffolk Transnational Law Review 227; Vaughan and Kilcommins, Terrorism (2008) (n 21) 124

${ }^{131}$ See P Martin, Censorship in the Two Irelands: 1922-39 (Dublin, Irish Academic Press, 2006).

${ }^{132}$ See, eg, Broadcasting Authority Act 1960 (BAA 1960); Broadcasting Authority (Amendment) Act 1976 (BAAA 1976), Radio and Television Act 1988, Broadcasting Act 1990, Broadcasting Authority (Amendment) Act 1993, and Broadcasting Act 2001.
} 
Republicanism. In the 1970s, for example, a Radió Telefis Éireann (RTÉ) Authority defending a program that criticised the government's handling of Northern Ireland was dismissed, as was a journalist who refused to provide the identity of an interviewee. ${ }^{133}$

The law also permits the prohibition of material sympathetic to paramilitary aims. As originally drafted, section 31(1) of the Broadcasting Authority Act, 1960 provided for the minister to 'direct the Authority in writing to refrain from broadcasting any particular matter or matter of any particular class.' For the first 11 years of the statute's existence, the government refrained from issuing any orders. In October 1971, though, RTÉ aired a number of interviews with members of the IRA. Gerry Collins, the Fianna Fáil Minister for Posts and Telegraphs, issued an order under section 31, directing RTÉ not to broadcast, 'any matter that could be calculated to promote the aims or activities of any organisation which engages in, promotes, encourages or advocates the attaining of any particular objectives by violent means' ${ }^{134}$

The vagarity of this wording led to tension between Collins, who suggested that it was up to RTÉ to interpret and apply the directive, and the RTÉ authority. ${ }^{135}$ The latter took the position that the directive did not ban the network from covering violence or statements issued by organisations claiming responsibility. ${ }^{136}$ Shortly thereafter, RTÉ management pulled an interview with two prisoners who had escaped from the Crumlin Road Gaol in Belfast. ${ }^{137}$

In 1972, tension between the government and the press escalated. During its annual meeting in April of that year, the NUJ raised serious concerns about government censorship. Just over six months later, on 19 November RTÉ Radio aired a report based on an interview with Seán MacStiofáin, IRA chief of staff. Collins pressed the RTÉ Authority on what action it intended to take. To appease him, the organisation decided that in the future such material would have to first be run by the station's director general. Unsatisfied, on 24 November Collins fired the authority. ${ }^{138}$ The next day the journalist who had made the report was sentenced to three months' imprisonment for failing to confirm that the individual whose voice could be heard on the tape was MacStiofáin. ${ }^{139}$ Within hours, journalists went on strike. ${ }^{140}$

On the first day of the NUJ's annual conference in 1974, the president of the union demanded that the government withdraw its section 31 directive. Conor Cruise O'Brien responded by requesting that he be allowed to address the delegates - a proposal roundly defeated. The conference went on to adopt a motion

\footnotetext{
${ }^{133}$ P Feeney, 'Censorship and RTE' (1984) 8[2] The Crane Bag 61, 64.

${ }^{134}$ Gerry Collins, Dáil Deb 4 November 1971, vol 256, col 1361; M O’Brien, The Fourth Estate: Journalism in TwentiethCentury Ireland(Manchester, Manchester University Press, 2017), p. 138.

${ }^{135}$ D G Morgan, 'Section 31: The Broadcasting Ban' 25 Ir Jur 117, 123.

${ }^{136}$ See D. Fisher, 'Getting tough with RTÉ', in M. Corcoran and M. O'Brien (eds), Political Censorship and the Democratic State: The Irish Broadcasting Ban (Dublin, 2005), pp. 61-72, cited in M. O'Brien, id at 139, n. 35.

${ }^{137}$ M O'Brien, id. at 138.

${ }^{138} \mathrm{Id}$.

${ }^{139} \mathrm{Id}$.

${ }^{140} I d$.
} 
calling for the government to rescind the directive and to restore RTÉ's 'right and [] duty to provide the public of Ireland with a free, impartial and balanced news and current affairs service. ${ }^{\text {141 }}$ Tensions between journalists and the government continued to mount.

In 1976, the Government amended the Broadcast Act, 1960 to read '[w]here the Minister is of the opinion that the broadcasting of a particular matter or any matter of a particular class would be likely to promote, or incite to, crime or would tend to undermine the authority of the State, he may by order direct the Authority to refrain from broadcasting the matter. ${ }^{142}$ The main difference between this language and that of section 31 in the original statute lay not in the ability of the Minister to intervene, but in creating conditions that had the effect of clarifying and in some ways strengthening the Minister's decision: i.e., where such material would be likely to promote criminal activity or to undermine the state. This language hewed more closely to the constitutional provisions in Article 40. ${ }^{143}$

As a procedural matter, the new statute also clarified that the written finding issued by the minister constituted an 'order,' bringing it within the Statutory Instruments Act 1947. ${ }^{144}$ The practical effect of this change meant that any orders issued would be subject to negative, rather than positive resolution, exempting the provision from any vote of the Oireachtas. Any such instrument would remain in force for 12 months, with the potential for indefinite renewal on an annual basis. Professor David Morgan, highlighting the importance of the negative resolution procedure, notes in his influential article on section 31 that neither a Government nor an Opposition party ever set time aside for such debate. ${ }^{145}$

Conor Cruise O'Brien followed the legislation with an order forbidding RTÉ from carrying any interview, or report of an interview, with a spokesperson for the IRA/Oglaigh na hÉireann; Provisional Sinn Féin; or any organisation proscribed by the British government under the Northern Ireland (Emergency Provisions) Act 1973. ${ }^{146}$ This clause brought Cumann na mBan; Fianna nah Eireann; Saor Eire, Ulster Volunteer Force; Ulster Freedom Fighters; and the Red Hand Commandoes within the reach of the Act. ${ }^{147}$

\footnotetext{
${ }^{141} I d$., at 143 .

${ }^{142}$ BAAA 1976, s 16 (inserting s 31(1) into the BAA 1960. The BAAA 1976, s 3 inserted similar language as s 18(1A) of the BAA 1960 (as part of impartiality, prohibiting the Authority 'from including in any of its broadcasts. . . anything which may reasonably be regarded as being likely to promote, or incite to, crime or as tending to undermine the authority of the State.') Professor Morgan, addressing the overlap between the sections, suggests that the essential difference is that 'section 18(1A) is directed, more or less... at activity, including speech, which is "likely to promote or incite to crime or ... to undermine the authority of the State".' Morgan, at 127. It is not as narrowly-focused as a criminal prosecution for conspiracy or incitement. 'By contrast, the thrust of the [Section 31] Order. . . is to prevent the use of broadcasting to foster sympathy for certain groups, principally Sinn Fein-IRA.' id at 127-128.

${ }^{143}$ See eg Article 40(3) (empowering the state to protect citizens from unjust attack); 40(6)(1)(i) (circumscribing 'the right of the citizens to express freely their convictions and opinions' to ensure that it not 'undermine public order or ... the authority of the State.'); and Article 40(6)(1)(iii) (limiting the citizens' right to assemble by explicitly authorizing laws to regulate and control associations in the public interest).

${ }^{144}$ Statutory Instruments Act, 1947, s. 1.

145 D G Morgan, 'Section 31: The Broadcasting Ban' 25 Ir Jur 117, 124.

146 Broadcasting Authority Act 1960 (Section 31) Order 1977, SI 1977/7.

${ }^{147}$ See Laura K. Donohue, Counterterrorist Law and Emergency Powers in Northern Ireland 1922-2000 (2007).
} 
The government extended these orders in 12 month increments, periodically expanding the list of organisations and eventually including Loyalist entities as well. ${ }^{148}$

The animosity that these orders engendered prompted Dr. Mark O’Brien, a Professor of Journalism History to observe, 'Overall, the 1970s and 1980s were a low point in media-state relations. ${ }^{149}$ In 1983, the newly-formed National Committee for Freedom of the Press and Broadcasting launched a campaign to secure the removal of all laws, including, inter alia, section 31 and portions of the OAS, which restricted public access to information. ${ }^{150}$ The organization's charter sought to 'create a climate of opinion conducive to a full, free and democratic flow of information, to ensure an independent and impartial press and broadcasting, to hold all power centres in Irish society responsible to an impartial media, to emphasise the obligation of journalists to present the truth and to remove the aura of secrecy which pertains to Irish society. ${ }^{151}$

Legal challenges to the government's use of section 31 met with varying levels of success. From 1976 to 1982 , the prohibition was directed at any 'interview or report of an interview with a spokesman' of the designated organisations. ${ }^{152}$ In 1982, in The State (Lynch) v. Cooney, the Supreme Court ultimately sustained the order, and section 31, as constitutional. ${ }^{153}$ In that case, a Sinn Féin candidate challenged a supplemental order issued by the Minister denying the party access to RTÉ facilities during the elections. ${ }^{154}$ O'Hanlon J ruled in the High Court 'that the decision given to the Minister, once he has formed his opinion, is an absolute discretion'. ${ }^{155}$ The Court did not have the authority 'to examine whether there [were] any reasonable grounds for the formation of such opinion' ${ }^{156}$ Coupled with Article 40.6.1(i) of the Constitution, prohibiting the airwaves from carrying paramilitary propaganda lay within the Government's purview. Nevertheless, the court ruled against the government - a decision subsequently overturned by the Supreme Court: the obligation of the State to ensure that 'organs of public opinion' not be used to undermine public

\footnotetext{
148 See, eg, Broadcasting Authority Act 1960 (Section 31) Order 1978, SI 1978/10 (banning broadcast for 12 months of IRA, Sinn Fein, UDA, EPA entities); Broadcasting Authority Act, 1960 (Section 31) Order 198, SI 1981/21; Broadcasting Authority Act, 1960 (Section 31) Order 1982, SI 1982/9; Broadcasting Authority Act, 1960 (Section 31) (No. 2) Order 1982, SI 1982/21; Broadcasting Authority Act, 1960 (Section 31) Order 1983, SI 1983/17; Broadcasting Authority Act 1960 (Section 31) Order 1987, SI 1987/13; Broadcasting Authority Act 1960 (Section 31) Order 1989, SI 1989/3; Broadcasting Authority Act 1960 (Section 31) Order 1983, SI 1983/17; Broadcasting Authority Act 1960 (Section 31) Order 1983, SI 1990/11; Broadcasting Authority Act 1960 (Section 31) Order 1983, SI 1991/6; Broadcasting Authority Act 1960 (Section 31) Order 1983, SI 1993/1. ${ }^{149} \mathrm{M}$ O’Brien, at 144.

${ }^{150}$ Irish Times, 14 June 1983, p. 6.

151 id.

${ }^{152}$ See eg Broadcasting Authority Act 1960 (Section 31) Order 1981, SI 1981/21, s 2 (stating, 'Radio Telefís Éireann is hereby directed to refrain from broadcasting any matter which is an interview, or report of an interview, with a spokesman or with spokesmen for any one or more of the following organisations...').

${ }^{153}$ See The State (Lynch) v Cooney [1982] IR 337 (SC) (O'Higgins CJ, holding the use of media to advocate overthrow of the state fell outside Constitutional protections).

${ }^{154}$ Broadcasting Authority Act 1960 (Section 31) Order 1982/21.

155 [1982] I.R. at 353-354.

${ }^{156}$ Ibid.
} 
order provided the grounds for constitutionally prohibiting speech supporting organizations calling for violent overthrow of the state. ${ }^{157}$

In 1993, the Supreme Court shifted course, unanimously upholding a High Court ruling that an individual could not be silenced solely based on membership in Sinn Féin. ${ }^{158}$ In O'Toole v. RTÉ, O'Flaherty $\mathrm{J}$ explained that an individual speaking on an anonymous topic on the airwaves, even if a member of a proscribed group, was not outside the constitutional guarantee of freedom of expression. ${ }^{159}$ Finlay CJ, joined by three other members of the court, emphasized that the application of the order to all speech by an member of Sinn Fein went well beyond section 31. That same year, the court sidestepped when RTÉ refused to accept a radio advertisement by Gerry Adams, President of Sinn Féin, based on the section 31 order. ${ }^{160}$ While an ordinary member of Sinn Féin might be protected, Adams was too closely associated with the core aims of the organization-leaving the ultimate decision to RTÉ. ${ }^{161}$

Throughout the Troubles, the British government's approach paralleled that of the Republic. It prevented the voices of members of any of the proscribed organisations from being carried on the airwaves. ${ }^{162}$ British law forbade the British Broadcasting Corporation (BBC) and the Independent Broadcasting Authority from transmitting 'any words spoken, whether in the course of an interview or discussion or otherwise. ${ }^{, 63}$ The Home Office followed passage of the statute with a letter to the BBC clarifying that the prohibition only applied to direct statements from members of the proscribed groups. ${ }^{164}$ Douglas Hurd defended the measures in Parliament: 'Those who live by the bomb and the gun and those who support them cannot in all circumstances be accorded the same rights as the rest of the population'. ${ }^{165}$ The media in Northern Ireland notoriously got around the British ban by using an actor's voice in the place of Republican speakers. A similar situation never arose in the South, as the Irish prohibition did not allow word-for-word broadcasts.

In 1991, several journalists, producers and two trade unions subject to broadcast bans argued in the European Commission on Human Rights that the prohibition violated their rights under Article 10 of the Convention. ${ }^{166}$ The applicants in Purcell v. Ireland asserted professional harm and the failure of section 31

\footnotetext{
${ }^{157}$ For a thoughtful discussions of O'Hanlon J's analysis in the High Court and O'Higgins C.J. in the Supreme Court, see Gerard Hogan, Demise of the Irish Broadcasting Ban, The, 1 Eur. Pub. L. 69, 71-73 (1995); and Morgan at 131-136.

${ }^{158}$ See O'Toole v. RTE (No 2), [1993] ILRM 458 (SC).

159 ibid (O'Flaherty, J) 467-68. See also ibid (Finlay, CJ) 464-65.

${ }^{160}$ Brandon Book Publishers Limited v RTE [1993] ILRM 806.

161 ibid (Carney, J). For further discussion of these cases, see see Gerard Hogan, Demise of the Irish Broadcasting Ban, The, 1 Eur. Pub. L. 69, 71-76 (1995).

162 Two orders accomplished the ban: the first to the British Broadcasting Corporation (BBC) and the other $t$ the Independent Broadcasting Authority (IBA). See Notice under Clause 13(4) of the BBC License and Agreement to the BBC and under section 29(3) of the Broadcasting Act 1981 (UK) to the Independent Broadcasting Authority, 19 October 1988; HC Deb 19 October 1988, vol 138, cols 893-903.

163 ibid.

${ }^{164}$ S Sottiaux, Terrorism and the Limitation of Rights: The ECHR and the US Constitution (Oxford, Hart Publishing, 2008$) 132$.

165 See also HC Deb 2 November 1988, vol 139, cols 1073.

166 Purcell and Others v Ireland, (1991) 70 DR 262.
} 
to meet the requisite 'prescribed by law' language in Article $10 \mathrm{~s} \mathrm{2.}{ }^{167}$ The Commission agreed that the order issued under section 31 interfered with the applicants' right to receive and impart ideas or information, but it rejected the claim that the law fell outside the prescribed limits. ${ }^{168}$ As to whether such restrictions were 'necessary in a democratic society,' it was difficult to strike the right balance 'between the requirements of protecting freedom of information and the imperatives of protecting the State and the public against armed conspiracies seeking to overthrow the democratic order which guarantees this freedom and other human rights. 169

The Commission concluded that on the whole, the Irish provisions were compatible with Article $10 \mathrm{~s}$ 2. ${ }^{170}$ The purpose was not to silence journalists, but to limit terrorists' ability to pursue their aims - a matter central to national security. ${ }^{171}$ Relative to print media, broadcast media held more power: it was 'more intimate', even as 'the possibilities ... to correct, qualify, interpret or comment on any statement made on radio or television' was more limited." ${ }^{172}$ Live broadcast, moreover, ran the risk of being used to carry out real-time operations — something that print reporters could avoid by screening material. ${ }^{173}$

In 1994, Michael D Higgins, the Irish Minister for Arts, Culture and the Gaeltacht did not seek renewal of the order. ${ }^{174}$ As the prominent scholar and jurist Gerard Hogan notes, the reason for its demise were complex, with pragmatic considerations taking center stage: the ban was not just unhelpful but counterproductive in that it gave opponents an opportunity to challenge the democratic nature of the state. ${ }^{175}$ Alternative provisions, such as the Prohibition of Incitement to Hatred Act, 1989 could be used more effectively to stem recruitment. ${ }^{176}$ Moreover, any real threat to the existence of the Irish government, had dissipated, making the debate one of principle: i.e., how much air time should be allotted to individuals engaged in violence. In 2001 the Oireachtas repealed the underlying provisions. ${ }^{177}$

\section{B. Censorship of Films}

\footnotetext{
167 ibid at 269-75.

168 ibid at 277 .

169 ibid at 279 .

170 ibid.

171 ibid.

172 ibid at 279-80.

173 ibid.

${ }^{174}$ Michael D Higgins, Dáil Deb 1 February 1994 vol 438, cols 226-27.

${ }^{175}$ Gerard Hogan, Demise of the Irish Broadcasting Ban, The, 1 Eur. Pub. L. 69, 76-77 (1995).

176 ibid at 77.

177 Broadcasting Authority Act 1960, s 31(1), as amended by Broadcasting Authority (Amendment) Act 1976, s. 16, repealed by Broadcasting Act 2001, s 3 .
} 
Irish law separately provides for censorship of films, advertisements, video, and DVD recordings. ${ }^{178}$ From the 1920s until the 1980s, the censorship board banned more than 2,500 films and cut over 11,000 more. ${ }^{179}$ Prominent stars and films, and work by well-known directors, such as Humphrey Bogart and Lauren Bacall in The Big Sleep (1946); Stanley Kubrick's Clockwork Orange (1971); Monty Python's Life of Brian (1979); Monty Python's The Meaning of Life (1983); and Oliver Stone's Natural Born Killers (1994) failed to pass muster. ${ }^{180}$ In 1957, the government brought a prosecution to prevent Tennessee Williams' The Rose Tattoo from being performed as it was 'an indecent and profane'. ${ }^{181}$

Although the board rejected most films on religious and moral grounds, some fell under the knife because of the level of violence or the manner in which they portrayed crime. In 1932, for instance, the Censorship Board rejected Scarface, a film loosely based on Al Capone's syndicate. Despite considering the film 'anti-gangster propaganda', that portrayed the law as 'triumphant', censors determined that, ultimately it pandered to sensationalism: 'If this propaganda is justifiable where will it stop? Similar realism might be offered for say - the white slave traffic - or other social evils'. ${ }^{182}$ When the producers re-submitted the film two decades later, the censors did not waver: 'This picture of the underworld is gangsterdom at its worst. Its features are violence, brutality, murders and loose women. Certificate refused'. ${ }^{183}$

The board rejected other films on ideological grounds. Thus, One Day in Soviet Russia, a 1941 Russian documentary portraying snapshots of life in the Soviet Union, fell outside acceptable bounds. ${ }^{184}$ Others, like the 1968 film Rocky Road to Dublin, challenged the legitimacy of the state.

The constitutionality of the provision was only challenged once-and not in relation to political violence. In Irish Family Planning Association v. Ryan, plaintiffs brought suit over censorship of a birth control pamphlet. ${ }^{185}$ They won the case, but on different, narrow grounds: failure of the censorship board to communicate its decision to the association.

In 2008, the Irish Film Censor's Office was re-cast as the Irish Film Classification Office (Oifig Aicmithe Scannán na hÉireann). The office now rates films according to their appropriateness for different age levels and only occasionally prohibits certain films on the grounds that they are indecent or obscene.

\footnotetext{
${ }^{178}$ See Censorship of Films Act 1923, Censorship of Films (Amendment) Act 1925, Censorship of Films (Amendment) Act 1930, Censorship of Films (Amendment) Act 1970, Video Recordings Act 1989, Censorship of Films (Amendment) Act 1992, and Blasphemy (Abolition of Offences and Related Matters) Act 2019.

179 'Irish Film Censors' Records 1923-38' (Trinity College Dublin) www.tcd.ie/irishfilm/censor/ accessed 25 February 2020.

${ }^{180}$ See 'The Land of Saints, Scholars and Censorship' (Independent.ie, 31 July 2012) https://www.independent.ie/lifestyle/theland-of-saints-scholars-and-censorship-26882364.html; Irish Central Staff, ‘Top Ten Movies Banned in Ireland' (Irish Central, 11 May 2017) https://www.irishcentral.com/roots/top-ten-movies-banned-in-ireland-124842519-237396851.

${ }^{181}$ AG v. Simpson (1959) 93 ILTR 33.

182 'Irish Film Censors’ Records, Scarface’ (Trinity College Dublin) www.tcd.ie/irishfilm/censor/show.php?fid=4765 accessed 25 February 2020.

183 ibid.

184 'Irish Film Censors' Records, One Day in Soviet Russia' (Trinity College Dublin) www.tcd.ie/irishfilm/censor/show.php?fid=5949 accessed 25 February 2020. 185 [1979] I.R. 295.
} 


\section{Censorship of Publications}

In 1929 the Oireachtas established a Censorship of Publications Board to consider complaints about indecent or obscene materials, or anything advocating 'the unnatural prevention of conception or the procurement of abortion or miscarriage'. ${ }^{186}$ Periodicals also could be prohibited where they devoted an undue amount of attention to crime. ${ }^{187}$ In 1946 the Oireachtas amended the statute to provide for a Publications Appeal Board. ${ }^{188}$ Just over twenty years later, it set a 12 year limit to banned works, with the potential for prohibition. ${ }^{189}$

Like films, most censored materials related to moral considerations. ${ }^{190}$ Some provided information about abortion. ${ }^{191}$ Others depicted gruesome attacks. ${ }^{192}$ A minority of the banned publications, such as The News of the World newspaper (prohibited in 1930) had a political bent. ${ }^{193}$ From the 1990s onward, the number of prohibited works decreased. Nevertheless, as of 2012, 274 books and periodicals were still banned. ${ }^{194}$ In 2003, 9 periodicals were banned. ${ }^{195}$ In 2016, for the first time in 18 years, the board censored a book on grounds of obscenity. ${ }^{196}$ Overall, sexual morality proved a much stronger driver than political aims for restricting public access to films and similar media.

\section{New Media, New Threats}

Despite the long history of censorship in Ireland, the general trend, acknowledged decades ago in the Hederman Report, has been to extend greater protections to speech and expression. ${ }^{197}$ To some extent, the shift has had to do with the democratization of dissemination of information, as well as access to it: it is far

\footnotetext{
${ }^{186}$ Censorship of Publications Act 1929, ss 3, 6(1).

${ }^{187}$ See 'Censorship of Publications Acts, 1929 to 1967, Register of Prohibited Publications' (Censorship of Publications Act, 1929 to 1967) (Justice.ie, 31 December 2016), www.justice.ie/en/JELR/Register_of_Prohibited_Publications_2016.pdf/Files/Register_of_Prohibited_Publications_2016.pdf. ${ }^{188}$ Censorship of Publications Act 1946.

189 Censorship of Publications Act 1967, ss 2(1), (3).

${ }^{190}$ See, eg, prohibitions on Pin-Up (1959), Man's Conquest (1960), Playgirl (1974), For Men Only (1959), and Climax (1975). Censorship of Publications Act, 1929 to 1967 (n 187).

${ }^{191}$ See, eg, prohibitions on Abortion: Right or Wrong? (1942), Abortion: Our Struggle for Control (1983), and The Complete Guide to Sex (1990). Censorship of Publications Act, 1929 to 1967 (n 187).

${ }^{192}$ See, eg, prohibitions on Murder Mysteries (1939), Crime Detective (1951), Complete Detective Cases (1952), and True Crime Cases (1951). Censorship of Publications Act, 1929 to 1967 (n 187).

${ }^{193}$ See Censorship of Publications Act, 1929 to 1967 (n 187).

${ }^{194}$ C Bohan, 'Censored: The 274 Books and Magazines Still Banned in Ireland Today' (TheJournal.ie, 21 May 2012) www.thejournal.ie/censored-the-274-books-and-magazines-still-banned-in-ireland-today-455034-May2012/.

195 Censorship of Publications, Charles Flanagan, Dáil Deb 1 February 2018, vol 964.

196 ibid; [2016] Iris Oifigiúil 388 [10]; Bohan, Censored (2012) (n 194); W O’Connor, 'Censor Bans First Publication in Ireland in 18 Years' (Independent.ie, 12 March 2016) www.independent.ie/entertainment/books/book-news/censor-bans-firstpublication-in-ireland-in-18-years-34533300.html.

197 Supra note 105 , at 6.3 .
} 
easier to control a handful of domestic newspapers and radio and television networks than to monitor everything written and disseminated online, worldwide — and accessible to anyone with a telephone. ${ }^{198}$ The change also relates to a shift in perspective. As the review committee explained, "political philosophy in the broad sense is not the same today as it was in 1939. Freedom of speech, even hurtful, untrue and dangerous speech, is regarded more positively. Hierarchical deference has given way to egalitarian norms, which are not sympathetic to the notion that those in positions of political power and responsibility should be immunized from harsh attack. ${ }^{199}$

Even as we have witnessed broader societal embrace of free speech, the conditions under which, historically, it was narrowed have altered. While violence continues in regard to the political status of Northern Ireland, the existential threat to the existence of the state from Republican dissidents has dissipated. As a result, legal constructs aimed at constraining that specific challenge can no longer rely on the immediate threat to the state for justification. To the extent that the threat is one of violence to persons or property, then a similar rationale to that underlying criminal provisions holds. Even if augmented based on the aims of the groups and individuals engaged in such activities, the impetus for Republican violence is not to undermine the political legitimacy of the Irish government.

What about contemporary threats that do present significant concerns about the stability of the state? Is the OAS sufficient to counter these? The provisions in the statute relating to speech were designed with a specific organisation, or set of associations, in mind. These groups operated in a similar fashion and used similar instruments to accomplish their goals. But the world in which we live has fundamentally altered. New media, in particular, can be used and manipulated by foreign governments, foreign movements, and others to create domestic social and political unrest-and to accomplish violent ends. While a full consideration of these threats is beyond the scope of this chapter, a brief discussion of two aspects - extremist ideology and terrorist recruitment, and the magnification of acts of terrorism —illustrate the point. For these, the OAS is utterly ill-suited to the task at hand.

\section{A. Extremist Ideology and Terrorist Recruitment}

One of the most serious consequences of social media is the way in which it alienates individuals and increases societal levels of isolation, depression and anxiety. Part of the problem is the structure itself: algorithms that preference similar views and trending material, the swift proliferation of emotionallyimbued information, and the 'like' function privilege extreme emotions. Of these, fear and anger fly most swiftly through the networks. Sophisticated algorithms pre-select what material users see, with the result

\footnotetext{
198 See also ibid at 6.2.

199 ibid at 6.3 .
} 
that individuals become not just more entrenched in their world views, but more extreme. The fact that other people are articulating outlying ideas, particularly when an algorithm feeds multiple such articulations into an individual's feed, creates a skewed world view: ie, that they are mainstream, when in fact, they are not. The situation becomes even more pronounced when botnets amplify certain messages, making it seem like 'trending' news, when it is not. The situation is ripe for organisations committed to violence to create greater sympathy for their cause and to recruit potential members. Because of the global nature of new media, they can do it from half a world away - anonymously. This is a very different situation than that which the Irish state has historically confronted.

Consider the role of social media as a recruitment platform. It runs 24 hours a day, seven days a week. It 'allows terrorists to reach out to their target audiences and virtually 'knock on their doors' - in contrast to older models of websites in which terrorists had to wait for visitors to come to them' ${ }^{200}$ Because of the massive amounts of data now available, the process can be highly individualised and difficult to detect. A group may seek out disenfranchised or disaffected people by tweeting, retweeting, or using popular hashtags related to divisive current events. By creating an online micro-community around the target, the individual develops a sense of comradery and belonging. The micro-community can then nudge the person to become increasingly isolated from others, before shifting the conversation to private social media platforms that have encryption, such as WhatsApp, Kik, or Telegram.

Global movements are taking advantage of these structures. The Islamic State (ISIS) has proven particularly savvy: at its height in 2015 , the network produced 38 daily batches of propaganda (i.e., videos, photos, photo essays, articles and audio programs). ${ }^{201}$ During the Islamic month of Shawwal, 17 July to 15 August 2015, the organization released 1146 batches of online propaganda. ${ }^{202}$ It was not disseminated through official online accounts: from 2014, ISIS had stopped making use of these on Twitter. Instead, the information was carried on accounts sympathetic to the organization-which on Twitter alone number upwards of 46,000 accounts, having an average of 1,000 followers each. ${ }^{203}$ ISIS also uses other social media sites, like YouTube, Google Drive, JustPaste.It, Google Photos, SendVid, and the Internet Archive. ${ }^{204}$ The aim of using these platforms is to generate sympathy for the cause and to increase the number of individuals

\footnotetext{
${ }^{200}$ G Weimann, 'New Terrorism and New Media' (Wilson Center Commons Lab, 2014) 3 www.wilsoncenter.org/sites/default/files/media/documents/publication/STIP_140501_new_terrorism_F.pdf.

${ }^{201} \mathrm{C}$ Winter, Documenting the Virtual 'Caliphate', London: Quilliam, 2015, p. 3, available at http://www.quilliaminternational.com/wp-content/uploads/2015/10/FINAL-documenting-the-virtual-caliphate.pdf. For a detailed discussion of ISIS's online activities, see Special Issue: Islamic State's Online Activity and Responses, 2014-2017, Studies in Conflict \& Terrorism 2019, vol. 42, Nos 1-2, 1-4.

202 ibid at 4.

203 ibid at 11; J M Berger and Morgan, The ISIS Twitter Consensus: Defining and Describing the Population of ISIS Supporters on Twitter, Washington, DC, Brookings, 2015, at 3, available at https://www.brookings.edu/wpcontent/uploads/2016/06/isis_twitter_census_berger_morgan.pdf.

${ }^{204}$ M Conway et al, 'Disrupting Daesh: Measuring Takedown of Online Terrorist Material and Its Impacts' (2019) 42 Studies in Conflict \& Terrorism 141.
} 
willing to take up arms. Their campaign has proven incredibly effective: scholars estimate that by 2017 ISIS had recruited more than 16,000 foreign fighters through this means. ${ }^{205}$

ISIS does not just use social media to recruit foreign fighters. It uses the platforms to encourage individuals to engage in violent acts in their own country as well. ${ }^{206}$ Subsequent action may be directed, or it may simply arise from a particularly insidious form of crowd sourcing: inspiring individuals, through their ideology, to undertake destructive acts. ${ }^{207}$

Social media, in turn, can provide resources for individuals to develop the knowledge and information necessary to mount subsequent attacks. ${ }^{208}$ A 2017 study of 223 terrorist offenders in the United Kingdom found, for instance, that in $61 \%$ of the cases there was evidence of online activities-ie., radicalization and/or attack planning. ${ }^{209}$ Forty-four percent of the perpetrators had found or downloaded extremist media, while more than half (54\%) went online to investigate some aspect of their intended attack-including whom to target and where to find them. The scholars who designed the study concluded that 'The Internet is largely a facilitative tool that affords greater opportunities for violent radicalization and attack planning. ${ }^{210}$ The use of new media was particularly pronounced for right-wing offenders, which, notably, are not in large numbers in the UK. ${ }^{211}$ This suggested that online social interactions - at the heart of new media - provide a way for individuals to find others of like mind, similarly bent on harming others. ${ }^{212}$

What does the 1939 OAS and its progeny have to say about this kind of challenge? Very little. Its prohibition on treasonable, seditious, or incriminating documents turns on proscribed, mostly Republican, organizations - not political views or opinions about recent events. ${ }^{213}$ Granted, unlike section 31 of the Broadcasting Act, associations do not have to be known by distinctive names in order to be unlawfulmaking, perhaps, those recruiting subject to prohibition. ${ }^{214}$

The Criminal Justice (Terrorist Offences) Act 2005 does make provision for international groups to be considered terrorist organizations. ${ }^{215}$ But in relation to the types of individuals targeted by groups like ISIS, the relevant posts may be news articles reporting on Government actions, or growing social or economic concerns - not direct engagement in terrorist activity or threats to do so. ${ }^{216}$ Here, the law explicitly protects

\footnotetext{
${ }^{205}$ S Klein and C Flinn, 'Social Media Compliance Programs and the War against Terrorism' (2017) 8 Harvard National Security Journal 53, 65 .

206 ibid.

${ }^{207}$ M Conway, 'Is Cyberterrorism a Real Threat? Yes: Why We Should Start from This Assumption' in R Jackson and D Pisoiu (eds), Contemporary Debates on Terrorism, 2nd edn (Abingdon, Routledge, 2018).

${ }^{208}$ P Gill et al, 'Terrorist Use of the Internet by the Numbers: Quantifying Behaviors, Patterns, and Processes' (2017)

16 Criminology and Public Policy 99.

209 ibid, at 107.

210 ibid.

211 ibid, at 110-111.

212 ibid at 113 .

213 OAS 1939, s 10(1)-(2); ibid s 2(a), (b), (c), (d).

214 ibid.

${ }^{215}$ Criminal Justice (Terrorist Offences) Act 2005, No. 2, s 5.

216 ibid, s 6(1).
} 
persons engaged 'in any protest, advocacy, or dissent.' ${ }^{217}$ The intent of disseminating such information is not to intimidate or to compel a government to act. ${ }^{218}$ It is to persuade.

The Criminal Justice (Terrorist Offences) (Amendment) Act 2015 altered the prior statute to try to get at provocation, recruitment, and training. ${ }^{219}$ The statute broadened the understanding of public provocation to include 'making available, by whatever means of communication by a person of a message to the public, with the intent of encouraging, directly or indirectly, the commission by a person of a terrorist activity. ${ }^{220}$ At first glance, this language seems broad enough to include political commentary or propaganda. But what happens when the distribution is undertaken by members of the general public, with no ties whatsoever to particular organisations or individuals? Or by algorithms developed by social media companies? Or bots intended to drive increased revenues? The same intent element required in relation to recruitment or training is similarly not met merely by how new media works. ${ }^{221}$

As for the OAS, even a rant about recent events may fall well short of material 'calculated to promote the formation' of an unlawful group, as forbidden by the statute. This type of material, moreover, is seen as the core of free speech-precisely the type of speech considered essential to modern democratic states. Even if the Irish government were to revert to prohibiting the types of violent materials outlawed under the censorship acts, much of the propaganda would still stand. ISIS and others are using messaging, and the structure of social media platforms - which drive individuals to more extreme views - to generate support and recruits.

There are further problems with applying the OAS and associated laws to the new media environment. First, is social media the equivalent of a newspaper? Or is it merely a form of communication? Posting is not the same as publishing. Individuals online may operate in their private capacity, limiting their communications to 'friends' - putting their thoughts and ideas at the core of how we think about free speech and freedom of association.

Second, material proliferates, literally, at the speed of light. So as soon as a comment is posted, it almost immediately may be picked up and re-posted by hundreds, or even thousands of people-making the prosecution of all of those involved in the circulation of such material preposterous. ${ }^{222}$ Nor can such material, in any way, be 'given up' to the Garda Síochána. ${ }^{223}$ Even erasing it online will fail to eradicate it from online caches. These are not documents that can be 'seized' or 'destroyed'.224

\footnotetext{
217 ibid, s 6(5).

${ }^{218}$ See ibid, s 6(7).

${ }^{219}$ Criminal Justice (Terrorist Offences) (Amendment) Act 2015, No. 17, ss 4, $5,6$.

220 ibid s 4.

${ }^{221}$ See ibid ss 5, 6.

${ }^{222}$ See OAS 1939, s 10(3).

223 ibid s 10(4).

${ }^{224}$ See ibid s 11(a), s 12(4).
} 
Third, the law makes it unlawful to possess certain documents. ${ }^{225}$ But the way new media works, users do not have control over material on their accounts. Sophisticated algorithms pick material for their feed. Those purchasing ads gain access without the user's permission. Where a user employs a particular hashtag, any number of comments may be generated on the same topic and be forwarded to their account.

Fourth, anonymity may make it almost impossible to ascertain who is posting the materials. In fact, it could be bots circulating information and adding content. And those pulling the strings need be nowhere near the country. A newspaper can be stopped at the border. Global communication systems cannot.

\section{B. Heightened Impact}

In 1974, Brian Jenkins famously observed, 'Terrorism is theater'. ${ }^{226}$ If an entity gets enough attention, it doesn't matter how big it is. It is being seen that creates fear and facilitates manipulation. New media has become a platform for those engaged in violence to magnify their actions. Accordingly, in 2014, ISIS branded their offensive \#AllEyesOnISIS to ensure that the world was watching.

Unlike in the past, where violent organisations have been dependent on the news media (which could be regulated), on the new platforms, they convey their own messages. They control the narrative and communicate directly with their audience. The more extreme the actions, the more emotions they generate, ensuring that the news moves even more swiftly through online communications. Violent extremists and terrorist organisations harness the power of others-including ordinary citizens - to get their message across. Thus, when Brenton Tarrant, a white supremacist, went on a rampage in Christchurch, New Zealand, killing 51 people, he announced that he was going to do it via $8 \mathrm{Chan} .{ }^{227} \mathrm{He}$ then broadcast the shooting on Facebook Live, YouTube, Twitter, and Instagram. ${ }^{228}$ During the attack, Tarrant shouted, 'Remember, lads, subscribe to PewDiePie' - a reference to an anti-Semitic YouTube channel with 89 million followers - the highest number on YouTube. ${ }^{229}$ These actions ensured maximum publicity.

Such incidents point to associated concerns. Posts circumnavigate Earth at the speed of light. The alternative legal structure on which the Irish government has previously depended to restrict terrorist publicity (section 31 of the Broadcast Act), was premised on prior identification of paramilitaries, as were

\footnotetext{
225 ibid s 12.

${ }^{226}$ BM Jenkins, 'International Terrorism: A New Kind of Warfare' (P-5261, RAND Corporation, 1974) 4 www.rand.org/content/dam/rand/pubs/papers/2008/P5261.pdf.

${ }^{227}$ See Associated Press, 'Death Toll from Christchurch Mosque Attack Grows to 51 After Turkish Man Dies' (NBC News, 2 May 2 2019) www.nbcnews.com/news/world/death-toll-christchurch-mosque-attacks-grows-51-after-turkish-man-n1001476; E Lopatto, 'The Mass Shooting in New Zealand Was Designed to Spread on Social Media' (The Verge, 15 March 2019) www.theverge.com/2019/3/15/18266859/new-zealand-shooting-video-social-media-manipulation.

${ }^{228}$ Lopatto, Mass Shooting (2019) (n 227).

229 ibid; 'Social Media's Role in Mosque Attack' (CBS News, 15 March 2019) www.cbsnews.com/video/disturbing-role-ofsocial-media-in-new-zealand-mosque-shooting/ (Social Media’s Role (2019)).
} 
many of the OAS measures. It is impossible to do this in relation to anyone (worldwide) with violent potential. Nor does Ireland control the platforms: almost all of the top social media companies are foreignowned, and some are foreign state controlled. Putting information up on a foreign server is not the same as printed material crossing the border. Organisations, additionally, can use social media not just to promote their own actions and 'brand', but to undermine the opponent's (or state's) narrative. ${ }^{230}$ This can become particularly insidious when paired with false information, much less deep fakes.

\section{Concluding Remarks}

One potential response to the insufficiency of the OAS might be to introduce new provisions that restrict the kind of material that can be carried by new media. Quite apart from the trend towards increasing protections for speech and expression, it is not clear that Ireland could take such actions and still meet its international legal obligations.

Article 10 of the European Convention of Human Rights (ECHR), protects free expression, meaning the right to hold opinions and 'to receive and impart information and ideas without interference'. ${ }^{231}$ The convention recognises that states can license broadcast, television, or cinema enterprises. And it protects restrictions 'necessary in a democratic society', introduced 'in the interests of national security', or adopted to prevent 'disorder or crime'. ${ }^{232}$ But disrupting online communities may trigger claims under Article 11, which protects peaceable assembly and association. ${ }^{233}$

In 2010, for instance, the ECHR considered a case in which Turkish magazine editors had been convicted for publishing statements made by members of illegal Marxist-Leninist groups. ${ }^{234}$ The Court rejected the country's effort to criminalize publication of statements by terrorist organisations, absent contextual consideration. Should identity be sufficient to preclude speech, Article 10 would fail to afford protection. Since the statements in question did not threaten or perpetuate violence, the national security justification failed to overcome Article 10 protections. Lynch v Cooney aside, the case raises question as to whether, under the Convention, Ireland could prohibit individuals from using social media purely on the basis of their identity. Like the ECHR, the Universal Declaration of Human Rights protects the right to freedom of opinion and expression. ${ }^{235}$

\footnotetext{
${ }^{230}$ M Borkowski, 'Isis and the Propaganda War: How the Social-Savvy Extremist Are Dominating the Headlines' (The Drum, 25 June 2014) www.thedrum.com/opinion/2014/06/25/isis-and-propaganda-war-how-social-savvy-extremists-are-qdominatingheadlines.

${ }^{231}$ Convention for the Protection of Human Rights and Fundamental Freedoms (ECHR) (1950) 213 UNTS 221, art 10.

232 ibid art 8.

233 ibid art 11.

${ }^{234}$ Gözel and Özer v Turkey App nos 43453/04 and 31098/05 (ECtHR, 6 July 2010).

${ }^{235}$ Universal Declaration of Human Rights (UDHR) (1948), UN Doc A/810 (1948) 71, art 19.
} 
The International Covenant on Civil and Political Rights (ICCPR) similarly guarantees the "freedom to seek, receive and impart information and ideas of all kinds, regardless of frontiers, either orally, in writing or in print, in the form of art, or through any other media of his choice. ${ }^{236}$ While national security may allow for some restrictions, freedom of opinion and expression are considered central to self-realisation and democratic governance - 'the foundation stone for every free and democratic society. ${ }^{237}$ They are integral to the right to vote. ${ }^{238}$ Freedom of opinion is so important that even in an emergency, states party cannot derogate from it. ${ }^{239}$ Individuals have the right to obtain all forms of audio-visual as well as electronic and internet-based modes of expression. ${ }^{240}$ The convention requires states 'to ensure universal access'. ${ }^{241}$

Under the ICCPR, protecting online expression matters because other rights rely on the free press, making it 'one of the cornerstones of a democratic society'. ${ }^{242}$ Without it, and the ability 'to comment on public issues without censorship or restraint' is compromised. ${ }^{243}$ The media, in turn, must be able to produce and to receive information. ${ }^{244}$ Social media, if anything, underscores the importance of the right. ${ }^{245}$ Statutes related to treason, sedition, or public order therefore must be drawn as narrowly as possible. ${ }^{246}$

In summary, numerous provisions in the OAS and associated laws have historically sought to contain the threat posed by Republican violence. The trend, though, is towards fewer direct restrictions on speech and expression. Simultaneously, the threat posed by Republicanism has altered. New media, moreover, facilitates threats fundamentally different than the traditional Republican challenge. Yet efforts to them may themselves fall afoul of Ireland's obligations under international law. It is not clear what the best way is to address the challenge. What is clear is that the OAS provisions that have historically regulated speech are increasingly inapposite to the types of challenges facing Ireland in the contemporary world.

\footnotetext{
${ }^{236}$ International Covenant on Civil and Political Rights (ICCPR) (1966) 999 UNTS 171, art 19.

${ }^{237}$ Human Rights Committee General Comment 34 (General Comment 34), CCPR/C/GC/34 (2011) para 2 (citing communication No 1173/2003, Benhadj v Algeria, Views adopted on 20 July 2007; No 628/1995, Park v Republic of Korea, Views adopted on 5 July 1996).

${ }^{238} \mathrm{See}$, eg, ICCPR arts 18, 25, 27 (freedom of expression integral to enjoyment of other rights (eg, assembly, association, right to vote)).

${ }^{239}$ General Comment 34, para 9; ibid para 5 fn 3.

${ }^{240}$ ibid, paras $11,12$.

241 'Freedom of Expression Everywhere, Including Cyberspace, Office of the High Commissioner' (UN Human Rights, Office of the High Commissioner, 4 November 2011) www.ohchr.org/EN/NewsEvents/Pages/Freedomofexpressioneverywhere.aspx.

242 General Comment 34, para 13 (citing communication No 1128/2002, Marques v. Angola, Views adopted on 29 March 2005).

${ }^{243}$ General Comment 34 (citing the Committee's general comment No 25, CCPR/C/GC/25 (1996) on article 25 (Participation in public affairs and the right to vote) para 25).

${ }_{244}$ General Comment 34, para 13 (citing communication No 633/95, Gauthier v Canada).

245 General Comment 34, para 15.

${ }^{246}$ See ibid paras 21, 29-31; Human Rights Committee, Consideration of Reports Submitted by States Parties under Article 40 of the Covenant Concluding Observations of the Human Rights Committee Hong Kong Special Administrative Region (HKSAR), $\mathrm{CCPR} / \mathrm{C} / \mathrm{HKG} / \mathrm{CO} / 2$ (2006).
} 